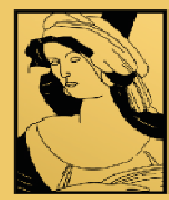

\title{
ALEXANDRIA
}

Revista de Educação em Ciência e Tecnologia

ALEXANDRIA

\section{História da Ciência em Livros Didáticos de Biologia: Os Conceitos de Genótipo e Fenótipo}

\section{History of Science in Biology Textbooks: Concepts of Genotype and Phenotype}

\author{
Aline Alves da Silva ${ }^{a}$; Lourdes Aparecida Della Justina ${ }^{b}$ \\ a Universidade Estadual de Maringá, Maringá, Brasil. - nyne_alves@ hotmail.com \\ b Universidade Estadual do Oeste do Paraná Cascavel, Brasil - lourdesjustina@gmail.com
}

Palavras-chave:

História da ciência.

Ensino de Biologia.

Livros didáticos.

Genótipo. Fenótipo.
Keywords:

History of science.

Biology teaching.

Textbook. Genotype.

Phenotype.
Resumo: A inserção da história e filosofia da ciência em aulas de Biologia no Ensino Médio é um fator relevante no processo de ensino e aprendizagem nessa disciplina escolar. O objetivo deste trabalho é apresentar e discutir os resultados de uma pesquisa acerca de como a história da ciência é apresentada em livros didáticos. A amostra envolveu 19 livros, datados de 1955 até 2006. Para análise dos dados, recorreu-se aos seguintes elementos da transposição didática: despersonalização do saber, envelhecimento moral/biológico e a dialética antigo/novo. A partir dos resultados obtidos, evidenciou-se que a maioria dos materiais não apresenta os aspectos históricos do desenvolvimento dos conceitos de genótipo e fenótipo, sendo que somente um dos livros analisados aborda a historicidade do processo de construção destes conceitos.

\begin{abstract}
The insertion of history and philosophy of science in biology classes of High School is a relevant factor in the teaching and learning process in this school subject. This paper aims to present and discuss the results of a research about how history of science is specified in textbooks. The sample involved 19 books, dated from 1955 to 2006. To analyze the data was used the following elements of the didactic transposition: depersonalization of knowledge, moral/biological ageing and the old/new dialectic. The results demonstrate that the most part of the samples did not reveal the historical aspects about the development of the genotype and phenotype concepts, in which only one of the books analyzed were discussed the historicity of the construction process of this concepts.
\end{abstract}




\title{
Introdução
}

Muitos autores defendem a inserção da história e filosofia da ciência no ensino de biologia, química e física, como Roberto Martins (2006c), Matthews (1995), Lilian Martins (2006a), Silva (2006) e Bizzo (1992). Pautando-se nesses autores, pode-se dizer que trabalhar a história e filosofia da ciência é fundamental para que os alunos compreendam que a ciência não é uma grande descoberta realizada em momentos de genialidade por uma única pessoa.

Deste modo, é importante que a história e a filosofia das ciências estejam presentes nos livros didáticos para dar subsídio aos professores e alunos que irão trabalhar com esses materiais. Entretanto, a memorização dos conceitos não deve ser a única preocupação dos professores, pois é preciso, além de entender os processos de construção do conhecimento, compreender o contexto de produção. Tal concepção mostra que

\begin{abstract}
Localizar o momento histórico em que um determinado conhecimento científico foi produzido é de especial importância no meio escolar, especialmente na sala de aula, pois, o professor pode inovar suas aulas, contribuir para o desenvolvimento do pensamento crítico em seus alunos e discutir com os mesmos que as teorias científicas não são definitivas e incontestáveis, e sim, que o mundo está sendo interpretado diferentemente a cada dia e que cabe a nós perceber essas interpretações, registrá-las e contestá-las (BATISTA et al., 2008, p. 2).
\end{abstract}

A pesquisa apresentada neste artigo teve como foco analisar a história da ciência presente nos livros didáticos destinados ao Ensino Médio, para tanto, o problema que esse estudo buscou responder foi: "como os livros didáticos destinados ao ensino de Biologia apresentaram ao longo do tempo a história da ciência referente ao desenvolvimento dos conhecimentos relacionados aos conceitos de genótipo e fenótipo?”.

Os conceitos de genótipo e fenótipo foram apresentados à comunidade científica, em 1911, por Wilhelm Ludvig Johannsen (1857-1927) em um artigo publicado na revista The American Naturalist intitulado "The genotype conception of heredity". Desde esta proposição, muitas mudanças e alterações ocorreram na forma como esses conceitos são compreendidos.

As maiores modificações ocorreram com a publicação na revista Nature do modelo de DNA, no artigo intitulado "A structure for desoxyribose nucleic acid", de autoria de James Watson e Francis Crick, em 1953, e com as pesquisas que se seguiram a partir desta divulgação, contexto no qual o genótipo deixa de ser considerado como uma unidade de cálculo, como relata Justina (2011), e passa a ser compreendido como o conjunto de genes que compõe o material hereditário.

A partir das pesquisas desenvolvidas e que tinham como base hereditária o DNA, os conceitos de genótipo e fenótipo foram (re)elaborados, como pode ser percebido no Quadro 1. 
Quadro 1: Descrição dos conceitos de genótipo e fenótipo aceitos pela comunidade científica desde a década de 1950 até os dias atuais.

\begin{tabular}{|c|c|c|}
\hline Período & $\begin{array}{l}\text { Ideias } \\
\text { predominantes } \\
\text { sobre os conceitos } \\
\end{array}$ & Descrição dos conceitos da relação genótipo e fenótipo \\
\hline $\begin{array}{l}\text { A partir dos } \\
\text { anos } 1950\end{array}$ & Transmissão & $\begin{array}{l}\text { Os filhos são semelhantes aos pais. Não há uma separação da } \\
\text { herança biológica de outros tipos de herança, como social, } \\
\text { econômica, etc., e não há uma distinção entre genótipo e fenótipo. }\end{array}$ \\
\hline $\begin{array}{c}\text { A partir dos } \\
\text { anos 1955-1960 }\end{array}$ & Molecular Clássico & $\begin{array}{l}\text { O genótipo é o conjunto de genes, sequências de DNA, presentes } \\
\text { nos cromossomos que codificam a produção de um polipeptídio ou } \\
\text { RNA, determinando as características fenotípicas. }\end{array}$ \\
\hline $\begin{array}{l}\text { A partir dos } \\
\text { anos } 1960-70\end{array}$ & $\begin{array}{c}\text { Genótipo + Ambiente } \\
=\text { fenótipo }\end{array}$ & $\begin{array}{l}\text { O genótipo é o conjunto de unidades de herança que são os genes - } \\
\text { fragmentos de DNA. O fenótipo é a manifestação do genótipo sob a } \\
\text { influência ambiental. }\end{array}$ \\
\hline $\begin{array}{c}\text { A partir de } \\
1980\end{array}$ & Perspectiva Evolutiva & $\begin{array}{l}\text { O genótipo é o conjunto de unidades de herança (fragmentos de } \\
\text { DNA) que competem pela sobrevivência e pela sua propagação, } \\
\text { mediante a expressão fenotípica. }\end{array}$ \\
\hline \multirow[t]{3}{*}{$\begin{array}{c}\text { A partir de } \\
1990 \text { em diante } \\
\text { mais pesquisas } \\
\text { foram } \\
\text { desenvolvidas } \\
\text { tendo essas } \\
\text { perspectivas } \\
\text { para os } \\
\text { conceitos de } \\
\text { genótipo e } \\
\text { fenótipo }\end{array}$} & Epigenética & $\begin{array}{l}\text { Envolve todas as mudanças reversíveis e herdáveis no genoma } \\
\text { funcional que não alteram a sequência de nucleotídeos do DNA. } \\
\text { Inclui o estudo de como os padrões de expressão são passados para } \\
\text { os descendentes, como ocorre a mudança de expressão espaço } \\
\text { temporal de genes durante a diferenciação de um tipo de célula e } \\
\text { como fatores ambientais podem mudar a maneira como os genes } \\
\text { são expressos. Existem três mecanismos principais de alterações } \\
\text { epigenéticas: metilação do DNA, modificações de histonas e ação } \\
\text { de RNAs não codificadores. }\end{array}$ \\
\hline & Processual & $\begin{array}{l}\text { Processo que integra uma ou mais sequências de ácidos nucléicos } \\
\text { (DNA ou RNA), correspondendo a um produto (polipeptídeo ou } \\
\text { RNA), mas que só é definida num determinado contexto de um } \\
\text { sistema. }\end{array}$ \\
\hline & $\begin{array}{c}\text { Genótipo }+ \\
\text { ambiente }+ \\
\text { organismo }= \\
\text { fenótipo } \\
\text { atual (estágio em que } \\
\text { se encontra o } \\
\text { indivíduo) }\end{array}$ & $\begin{array}{l}\text { Em uma visão sistêmica, o genótipo é o conjunto de indicativos } \\
\text { físico-químicos do desenvolvimento interno do organismo e que } \\
\text { permitem a construção do mesmo em caminhos para que o fenótipo } \\
\text { se assemelhe às gerações anteriores, dependendo das interações } \\
\text { ambientais. O fenótipo é a característica aparente de um organismo } \\
\text { em um determinado momento do desenvolvimento, fruto das } \\
\text { interações entre herança genotípica (indicadores do } \\
\text { desenvolvimento), ruídos do desenvolvimento (aspectos aleatórios } \\
\text { do desenvolvimento), herança ambiental, aspectos aleatórios do } \\
\text { ambiente e ação do organismo sobre seu ambiente. }\end{array}$ \\
\hline
\end{tabular}

Fonte: Adaptado de Justina (2011, p. 91) e de Schneider et al. (2011, p. 212).

Desta forma, com o intuito de responder ao questionamento "como os livros didáticos destinados ao ensino de Biologia apresentaram ao longo do tempo a história da ciência referente ao desenvolvimento dos conhecimentos relacionados aos conceitos de genótipo e fenótipo?", que norteou essa pesquisa, foram analisados 19 livros didáticos datados de 1955 a 2006. O período da datação dos livros iniciou-se em 1955 devido a marcação histórica que foi a publicação do artigo contendo o modelo de DNA em 1953 de James Watson e Francis Crick, esse artigo foi um marco relevante na história da ciência e no desenvolvimento da genética molecular, já o período que se estende até 2006 se deve a necessidade de analisar o desenvolvimento e atualizações desses materiais ao longo do tempo. Os critérios de classificação consistiram em uma análise prévia dos conceitos existentes em 74 livros então 
de acordo com a classificação dos conceitos foram sorteados os 19 livros, os quais analisou-se três elementos da transposição didática: a despersonalização do saber, o envelhecimento moral/biológico e a dialética antigo/novo, por entender que esses elementos seriam suficientemente satisfatórios para a realização deste trabalho.

\section{Os livros didáticos e a transposição didática}

A transposição didática é um tema relevante na busca para melhorar a educação. Assim, a teoria da transposição didática tem em Yves Chevallard um de seus principais fundamentadores. Marandino (2004), ao escrever sobre os saberes a serem ensinados, destaca que

[...] os conteúdos de saber designados como aqueles a ensinar são verdadeiras criações didáticas, suscitadas pelas necessidades do ensino. Esse trabalho de transformação de um objeto de saber em um objeto de ensino é o que ele chama de transposição didática (MARANDINO, 2004, p. 98).

O livro didático atua como intermediário entre o conhecimento científico e o conhecimento a ser ensinado aos alunos em sala de aula. Lajolo (1996) destaca a relevância da análise da qualidade dos conteúdos presentes nos livros didáticos a serem escolhidos pelos

professores. É necessário que esses conhecimentos estejam presentes de forma fundamentada, pois, se for com esse material que o aluno vai aprender os significados, é importante que se adeque à forma de aprendizagem com a qual a escola está comprometida e, também, com a sociedade na qual está inserida, visto que a escola não é desvinculada de seu contexto social.

Os professores são responsáveis pela escolha do livro didático a ser utilizado pela escola. Assim, esses livros, antes de chegarem para a avaliação do corpo docente nas escolas, passam por uma seleção realizada pelo Ministério da Educação (MEC). Cabe salientar que isso é válido (em parte) para professores da rede pública e alguns da rede privada. Entretanto muitas vezes o professor é apresentado ao sistema de apostila, isso ocorre pincipalmente na rede privada. Para efetuar esta escolha, o professor precisa estar capacitado para assumir as responsabilidades de sua seleção. Ele também precisa entender que os livros recomendados pelo MEC podem revelar várias limitações. Deste modo, esse material deve ser um entre as diferentes ferramentas a serem utilizadas pelo professor a fim de possibilitar uma educação em ciências que construa significados relevantes para o ensino e aprendizagem dos conteúdos científicos (NÚÑ̃Z et al., 2003).

Megid Neto e Fracalanza (2003) enfatizam a influência exercida por diversos setores na construção e na escolha das coleções didáticas utilizadas em sala de aula. Entre esses setores estão as editoras, que são responsáveis pela produção editorial, divulgação e pressão 
para a definição de normas, políticas e ações públicas, e as escolas e seu corpo docente, responsáveis pela seleção e avaliação das coleções. Contudo, pautados na sua concepção pedagógica, os professores precisam ser críticos e criativos na adaptação do livro à realidade da comunidade escolar para criar estratégias alternativas para utilizar o material no processo contextualizado de ensino e aprendizagem. Por fim, há outro setor que se constitui de pesquisadores que pesquisam e trabalham na produção de propostas metodológicas e de materiais didáticos alternativos, na formação continuada e atualização dos professores das escolas em relação aos conteúdos e metodologias de ensino, na assessoria e elaboração de propostas curriculares e, ainda, na produção de análise e divulgação de pesquisas relacionadas aos livros didáticos.

Pode-se perceber que muito ainda precisa ser alterado em todos os aspectos e instâncias que envolvem a produção, análise e utilização do livro didático. Lajolo (1996) aponta a necessidade de se estabelecer uma relação entre os conhecimentos prévios e os conteúdos existentes nos livros didáticos, pois "é só a partir do conhecimento que já têm do mundo em que vivem, que os alunos poderão construir os conhecimentos nos quais o livro didático e a escola devem iniciá-los" (LAJOLO, 1996, p. 5). Assim, o aluno tem a possibilidade de construir conhecimentos significativos para a sua vida por meio dos conteúdos científicos trabalhados em sala de aula. Núñes et al. (2003) destaca como o professor pode utilizar os livros com sabedoria mesmo que esses revelem diversas limitações. Sobre isso, os autores enfatizam que:

\begin{abstract}
O professor deve desenvolver saberes e ter competências para superar as limitações próprias dos livros, que por seu caráter genérico, por vezes, não podem contextualizar os saberes como não podem ter exercícios específicos para atender às problemáticas locais. É tarefa dos professores complementar, adaptar, dar maior sentido aos bons livros recomendados pelo MEC (NÚÑES et al., 2003, p. 3).
\end{abstract}

Contudo, existe a necessidade de que os livros estejam o mais próximo possível dos conceitos elaborados e aceitos pela comunidade científica. Para tanto, é imprescindível que os autores de livros didáticos se atentem ao desenvolvimento da ciência e se preocupem em transpor corretamente os conceitos científicos para esses materiais.

Neste sentido, sabe-se que os conceitos de genótipo e fenótipo se desenvolveram desde a sua proposição até o momento atual. Portanto, insistir em firmar esses conceitos de forma determinista pode acarretar em preconceitos por parte dos alunos e, até mesmo, pelos professores, que muitas vezes utilizam somente o livro como material de apoio e preparação para as aulas. 
Uma das vias para evitar problemas de cunho determinista é a utilização da história da ciência como intermediária nos processos de ensino e aprendizagem, além da abordagem de conceitos condizentes e da introdução de pesquisas mais atualizadas nesses materiais.

Koliopoulos et al. (2007) defendem que a utilização da história da ciência parece contribuir para a compreensão dos conceitos e métodos pelos alunos e para a criação de atitudes positivas em relação à ciência, ao mesmo tempo em que familiariza o professor da educação básica com os elementos da história da ciência.

Pensando nisso, e em problemas ainda a serem resolvidos e apontados acerca dos possíveis ajustes a serem realizados, neste trabalho propomos efetuar a análise dos livros didáticos em relação aos conceitos de genótipo e fenótipo com base em como se encontravam situados historicamente e como estão postulados nesses materiais.

É importante ressaltar, nesse contexto de escolha do livro didático, o papel relevante que tem a transposição didática e que é claramente exposta nesses livros. Essa transposição consiste em um processo percorrido pelo conhecimento até chegar ao aluno em sala de aula. Nesse processo, Chevallard (1991) denominou três tipos de saberes: "saber sábio", o saber dos cientistas, ou seja, os resultados das pesquisas publicadas; "saber a ser ensinado", este geralmente aparece nos materiais didáticos e currículos que servem de apoio para o desenvolvimento das aulas; e "saber ensinado", a aula em seu desenvolvimento. Neves e Barros (2011, p. 103) entendem esse fenômeno como "[...] o caminho realizado pelo saber desde sua elaboração científica até sua chegada em sala de aula como saber ensinado".

Menezes (2006) salienta que antes de o conhecimento científico chegar no "saber a ser ensinado", ele passa por uma série de transformações. Aos responsáveis por essa transição, Chevallard denominou-os de noosfera, os quais tem o dever de estabelecer o que precisa ser ensinado na escola. São, portanto, pessoas que irão elaborar e organizar os programas, as diretrizes e os livros didáticos. Esses normatizam e regulam o que deve ser ensinado na escola, assim, é estabelecida a transposição didática externa.

A transposição didática externa, conforme Chevallard (1991) e releitura de Neves (2009), com adaptação para análise de livros didáticos de Melzer (2012), passa por vários processos até chegar ao saber a ser ensinado, os quais são: desincretização do saber, despersonalização do saber, programabilidade do saber, publicidade do saber, fidelidade na textualização do saber, criações didáticas e, por fim, a dialética antigo/novo.

- Desincretização do saber: nesse processo é delimitado em que consiste o conceito em si, ou seja, divide o saber em saberes com o intuito de torná-lo mais didático. 
- Despersonalização do saber: consiste em deslocar os saberes da rede de conflitos e rupturas existentes em sua construção e desconstrução, sem mencionar os envolvidos em sua constituição devido o saber ficar disponível e suscetível à transformação.

- Programabilidade de saber: consiste em sequenciar o conteúdo a ser apresentado ao aluno. Essa programação tem o objetivo de facilitar a aprendizagem.

- Publicidade do saber: é quando o livro apresenta as razões para estudar determinado conteúdo.

- Envelhecimento moral/biológico: é quando o conhecimento científico não atende aos anseios da sociedade para a qual o material didático é direcionado. Assim, o conhecimento é modificado para atender aos anseios da sociedade (moral) e a ciência interfere obstinada a mostrar o conhecimento de uma forma diferente (biológico).

- Fidelidade na textualização do saber: esse ponto é referente à fidelidade do saber. Considera se as omissões existentes no livro didático podem prejudicar a compreensão do tema.

- Criações didáticas: são criações elaboradas com o intuito de facilitar a aprendizagem de conceitos complexos.

- A dialética antigo/novo: é quando se estabelece relação entre um conhecimento antigo com um conhecimento mais atualizado.

Já a transposição didática interna ocorre em sala de aula, na relação professor-aluno, no processo de ensino-aprendizagem ou por meio de situações de ensino organizadas pelo professor. Entretanto, essa transposição sofre várias influências externas e também passa por todo o processo de transformação do saber realizado pelo professor com o intuito de tornar o saber compreensível ao aluno em sua realidade social, econômica, histórica, cultural, entre outras (MENEZES, 2006).

Portanto, a escolha dos livros didáticos como material de análise para esta pesquisa ocorreu pelo fato de este material servir, muitas vezes, como o único material de apoio utilizado pelo professor em sala de aula. Deste modo, o livro didático passa a ser um ponto importante da transposição didática interna, pois assume o papel de "saber a ser ensinado" para os alunos.

\section{A História e Filosofia da Ciência e os livros didáticos}

Para discorrer sobre a história e filosofia da ciência nos livros didáticos é necessário 
entender como ela é difundida nesses materiais. Sobre isso, Carneiro e Gastal (2005) evidenciam que a história e filosofia da Biologia aparece nos livros didáticos tanto do Ensino Médio quanto do Ensino Superior como anedotas, ou seja, destaca-se a biografia de um único cientista, o que pode reforçar a ideia de genialidade científica. Os autores enfatizam, ainda, a linearidade científica, na qual é descrita uma sucessão de episódios que direcionariam "obviamente" a uma única forma de conhecimento, levando à concepção da ciência como pronta e acabada. Outro aspecto apontado é a ideia de consensualidade científica, em que não são apresentados os conflitos existentes na construção do conhecimento científico. Quando esses pontos conflitantes são mostrados, isso ocorre para mostrar a dualidade entre o conhecimento que estava "correto" e o conhecimento que estava "errado". Por fim, destaca-se também a ausência de um contexto histórico mais amplo que passe a ideia de que a ciência não é influenciada por fatores externos, como os aspectos socioculturais de cada período.

A pesquisa realizada por Pretto (1985) já evidenciava os problemas da a-historicidade dos livros didáticos, nos quais "a apresentação da ciência é absolutamente a-histórica. Sem referência ao seu processo de criação e muito menos ao contexto em que foi criada" (PRETTO, 1985, p. 77). Os problemas com a abordagem dos conteúdos nos livros didáticos não são recentes, já permeiam décadas. Mesmo com pesquisas que destacam tais falhas, atualmente ainda se tem dificuldades nas formas como esses conhecimentos são dispostos nesses materiais. Isso evidencia ainda mais a necessidade de realizar pesquisas referentes à qualidade dos livros que são utilizados em sala de aula.

Martins (2006), em sua pesquisa referente aos três conceitos presentes nos livros didáticos de Biologia (geração espontânea, teoria da evolução de Lamarck e a teoria cromossômica da hereditariedade), percebeu que a falha na exposição da história da ciência presente nos livros didáticos pode gerar distorções na aprendizagem dos alunos. A autora destaca alguns pontos de como essas formas equivocadas podem trazem danos na forma como a ciência é compreendida:

(1) Aquilo que atualmente aceitamos é correto e foi provado de forma definitiva por alguém no passado. (2) É possível se identificar quem fez e quando foi feita cada descoberta científica importante. (3) Na história da ciência, a os "heróis" (os que chegam a verdade) e os "vilões" (que só fazem confusões e comentem erros). (4) Os grandes cientistas do passado não se enganavam e já tinham chegado exatamente as ideias que aceitamos hoje em dia (MARTINS, 2006, p. 20).

Rosa e Silva (2010), ao investigarem sobre qual história está sendo apresentada nos livros de Biologia, visto que este é um dos critérios de avaliação do livro didático, concluem que as histórias que compõem os livros geralmente remetem a uma história de problemas. Baseando-se em Mayr, os autores descrevem esse tipo de história como: 
[...] a história de problemas, a qual se caracteriza pelo estudo dos problemas e não pelos períodos. Nessa concepção, os problemas científicos são compreendidos por meio de estudos de sua história, sendo que nessa abordagem é apresentada não apenas a história bem sucedida, mas também as tentativas fracassadas para a solução de problemas. Na história de problemas algumas questões devem ser consideradas, tais como a de especificar os problemas científicos do seu tempo, os instrumentos conceituais e técnicos de que se dispunha, os métodos utilizáveis, e as ideias influentes da época (ROSA; SILVA, 2010, p. 64).

No entanto, Silva et al. (2013), ao analisarem sete dos nove livros propostos pelo Programa Nacional do Livro para o Ensino Médio de 2009, chegaram à conclusão de que é possível, com as informações presentes nesses livros a respeito do tema ácido desoxirribonucleico (DNA), conduzir o aluno à concepção de ciência como uma construção histórica. Sobre isso os autores destacam que:

[...] podemos concluir que uma concepção de ciências baseada em uma abordagem relacional, embora possa ser considerada uma demanda filosófico-historiográfica, já possui condições de viabilidade nos livros didáticos, visto que, nestes, já estão presentes os elementos históricos indispensáveis para a apresentação de uma história de problemas (SILVA et al., 2013, p. 614).

Essas são algumas das pesquisas que investigam como a história da ciência é apresentada nos livros didáticos de Biologia. Deste modo, propõe-se investigar na presente pesquisa como a história da ciência dos conceitos de genótipo e fenótipo foram transpostos para os livros didáticos da escola básica, tendo como base para a análise os livros datados da década de 1950 até 2006.

\section{Metodologia da pesquisa}

Para configurar-se como uma pesquisa de cunho qualitativo, recorremos à análise de conteúdo, conforme proposto por Bardin (1977), seguindo os seguintes passos: pré-análise, codificação e categorização.

A primeira etapa da análise de conteúdo, a pré-análise, consiste em três processos: a escolha dos materiais a serem analisados, a formulação de hipóteses e dos objetivos, o que auxilia nas avaliações posteriores, e, por fim, a elaboração de indicadores que fundamentam a interpretação final (BARDIN, 1977). Nesse processo, definimos que os dados a serem analisados seriam decorrentes de como os conceitos de genótipo e fenótipo foram transpostos para os livros didáticos de biologia destinados ao Ensino Médio e se essa transposição considerou os aspectos históricos do processo de construção desses conceitos. Após a escolha, buscou-se a fundamentação teórica para dar subsídios às análises dos conceitos de genótipo e fenótipo e de como ocorre a transposição desses conhecimentos científicos para os livros didáticos. 
A segunda etapa, a codificação, é entendida como a organização dos dados e pode ser realizada primeiramente pelo recorte (escolha das unidades), seguida pela enumeração (escolha das regras de contagem) e, por fim, pela classificação e agregação (escolha das categorias), assim como propõe Bardin (1977). No segundo processo, realizamos as escolhas dos livros didáticos, os quais datam de 1955 até 2006, com o intuito de percorrer um determinado período histórico.

Em seguida, realizou-se a classificação dos livros conforme os anos de publicação, em que cada um foi codificado. Os livros, nos quais foi analisada a transposição didática, estão relacionados no quadro 2. Esses materiais foram codificados do mais antigo para o mais recente com códigos de LD1 a LD19 objetivando facilitar a compreensão.

Quadro 2: Relação de livros para a análise da transposição didática

\begin{tabular}{|c|c|c|c|c|c|c|}
\hline & Título do Livro & Autor(res) & $\begin{array}{c}\text { Ano de } \\
\text { publica } \\
\text { ção } \\
\end{array}$ & Editora & Cidade & $\begin{array}{l}\text { Código } \\
\text { do livro }\end{array}$ \\
\hline 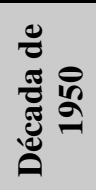 & $\begin{array}{l}\text { Biologia Educacional: } \\
\text { Noções Fundamentais }\end{array}$ & $\begin{array}{l}\text { ALMEIDA JUNIOR, } \\
\text { Antônio Fereira }\end{array}$ & 1955 & Nacional & $\begin{array}{c}\text { São } \\
\text { Paulo }\end{array}$ & LD1 \\
\hline \multirow{2}{*}{ 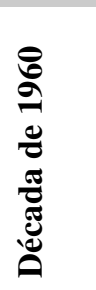 } & $\begin{array}{c}\text { Biologia: Das Moléculas } \\
\text { ao Homem }\end{array}$ & $\begin{array}{l}\text { KRASILCHIK, } \\
\text { Myrian; CLEFFI, } \\
\text { Norma Maria }\end{array}$ & 1967 & EDART & $\begin{array}{l}\text { São } \\
\text { Paulo }\end{array}$ & LD2 \\
\hline & Manual de Biologia & $\begin{array}{l}\text { FROTA PESSOA, } \\
\text { Oswaldo }\end{array}$ & 1967 & $\begin{array}{l}\text { Fundo de } \\
\text { Cultura }\end{array}$ & $\begin{array}{l}\text { São } \\
\text { Paulo }\end{array}$ & LD3 \\
\hline \multirow{4}{*}{ 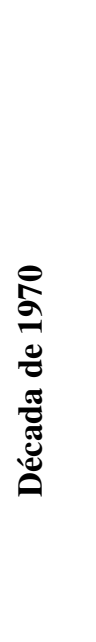 } & $\begin{array}{c}\text { Biologia: Conteúdo e } \\
\text { Programa do Colegial e } \\
\text { Vestibulares }\end{array}$ & FONSECA, Albino & 1970 & Ática & $\begin{array}{l}\text { São } \\
\text { Paulo }\end{array}$ & LD4 \\
\hline & $\begin{array}{l}\text { Biologia: Genética, } \\
\text { Evolução e Ecologia }\end{array}$ & $\begin{array}{c}\text { AMABIS, José } \\
\text { Mariano; MARTHO, } \\
\text { Gilberto Rodrigues; } \\
\text { MIZUGUCHI, } \\
\text { Yoshioto }\end{array}$ & 1974 & Moderna & $\begin{array}{l}\text { São } \\
\text { Paulo }\end{array}$ & LD5 \\
\hline & Biologia Auto-instrutivo & LOPES, Sônia & 1976 & Saraiva & $\begin{array}{l}\text { São } \\
\text { Paulo }\end{array}$ & LD6 \\
\hline & Elementos de Biologia & $\begin{array}{l}\text { BEÇAK, Maria Luíza; } \\
\text { BEÇAK, Willy }\end{array}$ & 1977 & FTD & $\begin{array}{l}\text { São } \\
\text { Paulo }\end{array}$ & LD7 \\
\hline \multirow{2}{*}{ 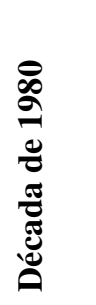 } & A Ciência da Biologia & $\begin{array}{c}\text { MARTHO, Gilberto } \\
\text { Rodrigues; AMABIS, } \\
\text { José Mariano }\end{array}$ & 1983 & Moderna & $\begin{array}{l}\text { São } \\
\text { Paulo }\end{array}$ & LD8 \\
\hline & $\begin{array}{c}\text { Biologia Básica: } \\
\text { Genética, Evolução e } \\
\text { Ecologia }\end{array}$ & SOARES, José Luiz & 1988 & $\begin{array}{l}\text { Scipione } \\
\text { LTDA }\end{array}$ & $\begin{array}{l}\text { São } \\
\text { Paulo }\end{array}$ & LD9 \\
\hline
\end{tabular}




\begin{tabular}{|c|c|c|c|c|c|c|}
\hline & $\begin{array}{c}\text { Ciências, Crítica e Ação: } \\
\text { 8 Série }\end{array}$ & $\begin{array}{l}\text { OLIVEIRA, Izabel } \\
\text { Martins Barros; } \\
\text { PAULA, Maria da } \\
\text { Conceição Ferreira; } \\
\text { VIMIEIRO, Maria das } \\
\text { Graças Monteiro; } \\
\text { SCHWENCK, } \\
\text { Terezinha do Carmo }\end{array}$ & 1989 & $\begin{array}{l}\text { Editora do } \\
\text { Brasil S/A }\end{array}$ & $\begin{array}{l}\text { São } \\
\text { Paulo }\end{array}$ & LD10 \\
\hline \multirow{5}{*}{ 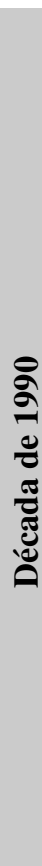 } & $\begin{array}{c}\text { Curso Completo de } \\
\text { Biologia Sintético e } \\
\text { Atualizado }\end{array}$ & $\begin{array}{l}\text { LOPES, Sônia G. B. } \\
\text { C.; LOPES, Plínio C. }\end{array}$ & 1991 & Saraiva & $\begin{array}{l}\text { São } \\
\text { Paulo }\end{array}$ & LD11 \\
\hline & Biologia Hoje: Volume 3 & $\begin{array}{c}\text { LINHARES, Sérgio; } \\
\text { GEWANDSZNAJDER } \\
\text {, Fernando }\end{array}$ & 1993 & Ática & $\begin{array}{l}\text { São } \\
\text { Paulo }\end{array}$ & LD12 \\
\hline & Biologia Ciência da Vida & $\begin{array}{l}\text { MARCONDES, } \\
\text { Ayrton César; } \\
\text { LAMMOGLIA, } \\
\text { Domingos Ângelo }\end{array}$ & 1994 & Atual & $\begin{array}{l}\text { São } \\
\text { Paulo }\end{array}$ & LD13 \\
\hline & BIO 3 & $\begin{array}{l}\text { LOPES, Sônia Godoy } \\
\text { Bueno Carvalho }\end{array}$ & 1995 & Saraiva & $\begin{array}{l}\text { São } \\
\text { Paulo }\end{array}$ & LD14 \\
\hline & $\begin{array}{c}\text { Biologia Programa } \\
\text { Completo }\end{array}$ & $\begin{array}{c}\text { LINHARES, Sérgio; } \\
\text { GEWANDSZNAJDER } \\
\text {, Fernando }\end{array}$ & 1999 & Ática & $\begin{array}{l}\text { São } \\
\text { Paulo }\end{array}$ & LD15 \\
\hline \multirow{4}{*}{ 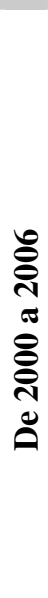 } & Conceitos de Biologia & $\begin{array}{c}\text { AMABIS, José } \\
\text { Mariano; MARTHO, } \\
\text { Gilberto Rodrigues }\end{array}$ & 2001 & Moderna & $\begin{array}{l}\text { São } \\
\text { Paulo }\end{array}$ & LD16 \\
\hline & Biologia & $\begin{array}{l}\text { PAULINO, Wilson } \\
\text { Roberto }\end{array}$ & 2004 & Ática & $\begin{array}{l}\text { São } \\
\text { Paulo }\end{array}$ & LD17 \\
\hline & Biologia & $\begin{array}{c}\text { AMABIS, José } \\
\text { Mariano; MARTHO, } \\
\text { Gilberto Rodrigues }\end{array}$ & 2004 & Moderna & $\begin{array}{l}\text { São } \\
\text { Paulo }\end{array}$ & LD18 \\
\hline & $\begin{array}{l}\text { Biologia Para o Ensino } \\
\text { Médio: Curso Completo }\end{array}$ & $\begin{array}{c}\text { LAGO, Samuel } \\
\text { Ramos; CROZETTA, } \\
\text { Marcos }\end{array}$ & 2006 & IBEP & $\begin{array}{l}\text { São } \\
\text { Paulo }\end{array}$ & LD19 \\
\hline
\end{tabular}

Fonte: Dados da Pesquisa

A terceira etapa consistiu a categorização. Esta corresponde, conforme descrito por Bardin (1977, p. 117), da seguinte maneira:

A categorização é uma operação de classificação de elementos constitutivos de um conjunto, por diferenciação e, seguidamente, por reagrupamento segundo o gênero (analogia), com os critérios previamente definidos. As categorias, são rubricas ou classes, as quais reúnem um grupo de elementos (unidades de registro, no caso da análise de conteúdo) sob um título genérico, agrupamento esse efetuado em razão dos caracteres comuns desses elementos. 
Procurou-se investigar somente os elementos que se relacionavam à maneira como a história da ciência dos conceitos de genótipo e fenótipo eram apresentados nos livros analisados. Assim, foram criados questionamentos condizentes aos elementos que se relacionam à forma como a história da ciência é apresentado nos livros. Os elementos (Categorias) são apresentados a seguir com seus respectivos questionamentos:

\section{Despersonalização do saber}

1. Faz a relação dos conflitos científicos existentes sobre a definição desses conceitos (genótipo e fenótipo)?

2. Menciona pelo menos alguns dos envolvidos na constituição dos conceitos de genótipo e fenótipo, visto que é bastante complicado fazer todo o retrospecto histórico em um livro didático?

\section{Envelhecimento moral/biológico}

3. Ao longo da história, o saber é reestruturado (modernizado) para atender a certas demandas sociais?

4. Algum conceito relacionado ao genótipo e fenótipo é retirado ou adicionado ao longo das reformas?

\section{A dialética antigo/novo}

5. O livro didático faz uma abordagem de algum processo de desenvolvimento histórico no capítulo em que apresenta os conceitos de genótipo e fenótipo relacionando-o com o conhecimento de cada época? Se faz, de que forma isso ocorre?

\section{Resultados e discussão}

No tópico a seguir serão apontados os resultados, juntamente com a discussão da análise realizada nos livros didáticos, relacionados às questões envolvendo a história da ciência dos conceitos de genótipo e fenótipo presentes nesses materiais.

\section{Despersonalização do saber}

$\mathrm{Na}$ análise dos materiais para essas duas questões correspondentes à despersonalização do saber, verificou-se que nenhum dos livros apresenta os conflitos existentes para a constituição dos conceitos de genótipo e fenótipo. Entretanto, em um dos livros há uma nota explicativa ao lado do texto, na página posterior à definição dos conceitos onde se define o que seria genótipo e fenótipo, na qual os autores relatam sobre as constantes mudanças que ocorrem na definição de conceitos científicos. Isso pode ser evidenciado no trecho a seguir: 
Uma das vantagens do conhecimento científico é que ele é capaz de corrigir-se e aperfeiçoar-se. Devemos lembrar que qualquer teoria pode, no futuro, ser refutada por outras experiências e substituídas por uma nova teoria que explique melhor os fatos. As teorias são portanto, explicações parciais e temporárias que, após rigorosos testes, serão aceitas, provisoriamente pela comunidade científica. Assim, o verdadeiro cientista sabe que no campo da ciência não há verdades absolutas ou eternas e deve estar sempre pronto para abandonar uma teoria quando está for contrariada pela experiência. (LD12)

Como é percebido neste fragmento, os autores apontam para o caráter provisório do conhecimento científico, mesmo que não tragam especificamente sobre os conflitos existentes para a construção dos conceitos de genótipo e fenótipo. Eles mencionam que a ciência não é uma verdade absoluta e que se encontra em constante mudança, o que representa um avanço este reconhecimento estar presente nos livros didáticos, especialmente em se tratando de um livro datado dos anos 1990.

Como é apresentada a nota no livro, é possível verificar, conforme Briccia e Carvalho (2011, p. 9), “o caráter provisório e histórico existente na construção do conhecimento científico, uma vez que o conhecimento anteriormente aceito já não se coloca como suficiente para a explicação de novas teorias".

Quanto à questão dois, somente em dois livros (LD7 e LD18) menciona-se apenas o nome de Johannsen, que foi quem propôs os termos genótipo e fenótipo, como pode ser percebido nos fragmentos que se seguem:

\footnotetext{
Johannsen, em 1911, propôs o termo genótipo para designar a constituição hereditária que um ser recebe dos pais através dos gametas, e fenótipo para designar a aparência de um individuo, ou seja, a soma total de suas peculiaridades de forma, tamanho, cor, comportamento externo e interno. (LD7)

Dois conceitos importantes em genética, introduzidos na literatura científica pelo pesquisador dinamarquês Wilhelm L. Johannsen [...] em 1909, foram genótipo e fenótipo. (LD18)
}

O livro LD7 somente menciona o introdutor destes termos e não relata nada sobre as mudanças na definição destes conceitos ao longo do tempo, desde sua proposição até o momento de elaboração do livro. Entretanto, em se tratando de um livro datado da década de 1970, é compreensível essa atitude positivista quanto à "descoberta" e pontualidade de uma teoria científica.

Já o livro LD18 traz um capítulo específico para explicar o desenvolvimento da genética molecular e, por consequência, as mudanças decorrentes desse processo. A seção do livro, intitulada "Do genótipo ao fenótipo: como se expressam os genes", faz um levantamento histórico da constituição da genética molecular e relaciona as mudanças que ocorreram no entendimento desses termos com todas essas variações. 
Entretanto, como destacam Rosa e Silva (2010), a pontualidade e linearidade com que os livro didáticos apresentam a história da ciência não favorece a reflexão de como ocorreu a construção desse conceito. Essa forma de expressar limita a capacidade investigativa do aluno visto que se concentra em datas e fatos, negligenciando a contextualização histórica dos acontecimentos.

Com essa análise, portanto, pode-se perceber a necessidade de melhorar como a história da ciência, relacionada aos conceitos de genótipo e fenótipo, é abordada nos livros didáticos. Ainda, também se evidencia que esses materiais não fazem a contextualização do processo de construção desses conceitos. Assim, para alcançar o objetivo de inserção do desenvolvimento dos conhecimentos, é necessária uma mobilização coletiva de autores e editoras. Todavia, como destaca Martins (2007, p. 127), "a produção de material didático de qualidade [...] não é o único problema a ser considerado no contexto de dificuldades a serem enfrentadas", o que mostra a necessidade de se trabalhar a inserção da história e filosofia da ciência nos cursos de graduação.

\section{Envelhecimento moral/biológico}

Para responder ao questionamento de número três, pode-se afirmar que, com a análise dos livros, percebe-se que com o passar do tempo e com o desenvolvimento do conhecimento a forma como os conceitos de genótipo e fenótipo foram apresentados variaram e se modificaram. A mudança mais visível ocorreu na forma como os conceitos passaram a ser divulgados a partir dos anos 1970 com a renovação e transposição do conhecimento científico e social para os materiais didáticos, isso com uma demora de vinte anos. Com o advento do fim da Segunda Guerra Mundial, apontar o genótipo do indivíduo como determinante do seu fenótipo passou a ser problemático, visto que o preconceito, em parte gerado pelo determinismo genético, originou e ainda origina grandes problemas sociais.

Como os adventos evidenciados durante a Segunda Guerra Mundial, momento no qual o movimento eugênico, segundo Schneider et al. (2012), foi muito influente nos períodos finais do século XIX e até a metade do século XX, difundiu-se o pensamento de que se poderia melhorar a espécie humana por meio de controle da reprodução. Esse pensamento era baseado na ideologia referente à biologia vigente na época, em que se acreditava que a melhora da raça humana acarretaria no progresso das nações.

A eugenia é claramente evidente na limpeza racial, que foi realizada no período que antecedeu e durante a Segunda Guerra Mundial. Porém, ainda hoje encontram-se problemas bioéticos presentes nas sociedades, como nos programas de melhoramento genético, 
fecundação in vitro, engenharia genética, entre outros. Entretanto é preciso discussões aprofundadas sobre esses temas, não se pode barrar o desenvolvimento da ciência isso seria um retrocesso, porem precisam ser refletidas de forma fundamentada as consequências desse desenvolvimento. Quanto a isso Barth (2005, p. 374) destaca:

A ciência não tem limites, e sempre, quando ela se defronta com eles, tende a alargálos para mais longe. Existem limites técnicos e éticos a serem respeitados. Essa tarefa exige repensar valores humanos, além de atualizá-los e transmiti-los às novas gerações. Se, durante a era industrial, a educação se preocupava em formar técnicos, hoje percebemos que é necessário o retorno da educação integral, ou seja, uma educação que, além de formar excelentes profissionais técnicos, forme também pessoas e cidadãos.

Os livros que apresentam essa forma de expressar o conhecimento sobre os conceitos de genótipo e fenótipo, como sendo influenciado por outros fatores que não somente a determinação genética, encontra-se presente nos livros datados de 1977 (LD7), 1989 (LD10), 1994 (LD13) e 2001 (LD16). Estes materiais trazem essa concepção da seguinte forma:

O fenótipo é resultado da interação do genótipo com o ambiente. [...] Quanto maior o número de variações ambientais maior o número de fenótipos possíveis. (LD7)

Em alguns casos o fenótipo pode ser mudado pelo ambiente. Uma criança que recebeu dos pais os genes que condicionam a característica de canhota, pode aprender a usar a mão direita para escrever, por insistência dos pais ou professores. Neste caso, ela mudou o seu fenótipo, mas não o seu genótipo. (LD10)

O fenótipo pode ser expresso pela seguinte relação: Fenótipo = genótipo + ambiente. Essa relação pode ser mostrada quando se estuda os gêmeos univitelinos [...] se estes forem separados, o mais cedo possível, e criados por casais diferentes, em meios distintos, com toda certeza apresentarão fenótipos diferentes. (LD13)

Os cientistas concluíram que o fenótipo resulta da interação entre o fenótipo e o ambiente. Por exemplo, duas pessoas com exatamente os mesmos genes para cor da pele terão diferentes fenótipos (pele mais clara ou mais escura) dependendo do tempo que cada uma delas fica exposta ao sol. (LD16)

Nos materiais analisados verificou-se a indicação do ambiente como fator importante na formação do fenótipo dos indivíduos. Contudo, pode-se perceber em LD16, mesmo datado depois dos anos 2000, que não existe mensão significativa de que o ambiente é um fator importante na expressão gênica, e que, portanto, o genótipo não determina o fenótipo. Ao contrário, neste mesmo capítulo do livro podem ser encontrados indicativos da concepção de que o genótipo é determinante do fenótipo, isso sem mencionar o ambiente interno ou externo ao indivíduo e nem o desenvolvimento e as interações de ambos os fatores. Isto pode ser percebido no fragmento a seguir:

As "versões" materna e paterna de cada gene podem não ser idênticas. Um gene que determina a cor da pelagem em ratos, por exemplo, ocorre em duas versões, uma que condiciona pelagem marrom e outra que condiciona pelagem branca; um gene para cor da flor boca de leão também ocorre em duas versões, uma que determina flores vermelhas e outra que determina flores brancas; na espécie humana, um gene que determina o tipo de lobo da 
orelha também possui duas versões, uma para lobo preso ou aderente (grudado ao rosto) e outra para lobo livre. (LD16)

Essa forma de pensamento determinista na educação gera grandes problemas. Um destes é apontado por Becker (2013) que destaca a concepção apriorista que alguns professores possuem em relação a como o aluno aprende. Esses docentes entendem que a possibilidade de o aluno aprender ou não são dadas na bagagem hereditária, de configuração inata ou subordinadas ao processo de amadurecimento, porém, de qualquer maneira são predeterminadas. Esta forma de compreensão do desenvolvimento da aprendizagem relativiza a experiência.

Como se percebe, essa é uma das razões para nos opormos à concepção de determinismo genético, entretanto, podem-se citar várias outras, como o preconceito, a formação de estereótipos, a rotulação de sujeitos pela aparência ou pela situação, entre outros.

Existem, também, outras mudanças decorrentes principalmente do desenvolvimento do conhecimento científico, como acrescentar na composição do fenótipo o desenvolvimento, o meio interno e externo, as reações fisiológicas, entre outras, como importantes para a formação do fenótipo e para a não restrição do fenótipo à aparência externa do organismo. É possível perceber essas mudanças no fragmento que se segue:

O termo fenótipo é empregado para designar as características morfológicas, fisiológicas ou comportamentais apresentadas por um indivíduo [...] o fenótipo também engloba características microscópicas e de natureza bioquímica [...] o fenótipo resulta da interação do genótipo com o ambiente [...] o fenótipo também se transforma com o passar do tempo. (LD18)

Para responder ao questionamento quatro, que corresponde a "Algum conceito relacionado a genótipo e fenótipo é retirado ou adicionado ao longo das reformas?", recorrese a uma tabela onde são elencados os termos que são retirados ou adicionados aos conceitos presente em cada livro. A relação é do livro anterior para o livro posterior. 
Quadro 3: conceitos adicionados e retirados dos livros com o passar do tempo

\begin{tabular}{|c|c|}
\hline $\begin{array}{l}\text { Código do } \\
\text { livro }\end{array}$ & Conceitos adicionados \\
\hline LD1 & $\begin{array}{l}\text { Genótipo: conjunto de propriedades genéticas, expressas ou latentes. } \\
\text { Fenótipo: aparência exterior. }\end{array}$ \\
\hline LD2 & $\begin{array}{l}\text { Genótipo: "Fórmula Gênica" } \\
\text { Fenótipo: Aspecto de um organismo }\end{array}$ \\
\hline LD3 & $\begin{array}{l}\text { Genótipo: A constituição genética. } \\
\text { Fenótipo: Sua aparência. }\end{array}$ \\
\hline LD4 & $\begin{array}{l}\text { Genótipo: Constituição hereditária } \\
\text { Fenótipo: Aparência do indivíduo [...] expressas na forma, cor, tamanho, comportamento tanto } \\
\text { externas como internas. }\end{array}$ \\
\hline LD5 & $\begin{array}{l}\text { Genótipo: Material hereditário [...] constituído pelos genes das células. } \\
\text { Fenótipo: Todos os caracteres apresentados por um organismo, sejam morfológicos, } \\
\text { fisiológicos ou comportamentais [...] pode sofrer transformações com o passar do tempo. }\end{array}$ \\
\hline LD6 & $\begin{array}{l}\text { Genótipo: O conjunto de genes do indivíduo. } \\
\text { Fenótipo: Expressão do genótipo. }\end{array}$ \\
\hline LD7 & $\begin{array}{l}\text { Genótipo: Constituição hereditária. } \\
\text { Fenótipo: Resultado da interação do genótipo com o ambiente [...] aparência de um indivíduo, } \\
\text { ou seja, a soma total de suas peculiaridades de forma, tamanho, cor, comportamento externo e } \\
\text { interno. }\end{array}$ \\
\hline LD8 & $\begin{array}{l}\text { Genótipo: Designa a constituição genética do indivíduo. } \\
\text { Fenótipo: Todos os caracteres apresentados por um organismo, sejam morfológicos, } \\
\text { fisiológicos ou comportamentais [...] o fenótipo de um indivíduo sofre transformações com o } \\
\text { passar do tempo. [...] está sujeito a alterações determinadas pelo ambiente. }\end{array}$ \\
\hline LD9 & $\begin{array}{l}\text { Genótipo: Constituição genética de um indivíduo. } \\
\text { Fenótipo: É expressão da atividade do genótipo, mostrando-se como uma manifestação visível, } \\
\text { ou de alguma forma detectável do caráter considerado. }\end{array}$ \\
\hline LD10 & $\begin{array}{l}\text { Genótipo: Conjunto de genes responsáveis por um carácter hereditário. } \\
\text { Fenótipo: Expressão do genótipo associada às influências do ambiente. }\end{array}$ \\
\hline LD11 & $\begin{array}{l}\text { Genótipo: O conjunto total de genes de um indivíduo ou cada par de genes em particular. } \\
\text { Fenótipo: Conjunto das variáveis dos caracteres manifestados em um organismo. Variável de } \\
\text { cada carácter em particular. }\end{array}$ \\
\hline LD12 & $\begin{array}{l}\text { Genótipo: O conjunto de genes. } \\
\text { Fenótipo: O conjunto de características morfológicas ou funcionais de um indivíduo. }\end{array}$ \\
\hline LD13 & $\begin{array}{l}\text { Genótipo: É o patrimônio genético de um organismo. } \\
\text { Fenótipo: É aparência, o aspecto externo de um indivíduo. }\end{array}$ \\
\hline LD14 & $\begin{array}{l}\text { Genótipo: Pode ser aplicado tanto ao conjunto total de genes de um indivíduo como a cada par } \\
\text { de genes em particular. } \\
\text { Fenótipo: Pode ser aplicado tanto ao conjunto das variáveis dos caracteres manifestados em um } \\
\text { organismo como a variável de cada caráter em particular. }\end{array}$ \\
\hline LD15 & $\begin{array}{l}\text { Genótipo: O conjunto de genes que um indivíduo possui em suas células. } \\
\text { Fenótipo: O conjunto de características morfológicas ou funcionais do indivíduo. }\end{array}$ \\
\hline LD16 & $\begin{array}{l}\text { Genótipo: Os tipos de genes que um organismo possui. } \\
\text { Fenótipo: As características observáveis de um organismo. }\end{array}$ \\
\hline LD17 & $\begin{array}{l}\text { Genótipo: Constituição genética de um indivíduo. } \\
\text { Fenótipo: As características que se manifestam em um indivíduo, quer sejam elas de ordem } \\
\text { morfológica, quer fisiológica. }\end{array}$ \\
\hline LD18 & $\begin{array}{l}\text { Genótipo: Refere-se à constituição genética do indivíduo, ou seja, aos tipos de alelos que ele } \\
\text { possui. } \\
\text { Fenótipo: É empregado para designar as características morfológicas, fisiológicas ou } \\
\text { comportamentais apresentadas por um indivíduo [...] o fenótipo também engloba características } \\
\text { microscópica e de natureza bioquímica. }\end{array}$ \\
\hline LD19 & $\begin{array}{l}\text { Genótipo: É o patrimônio hereditário, ou seja, um conjunto de genes que um indivíduo recebeu } \\
\text { de seus pais. } \\
\text { Fenótipo: É a característica presente no indivíduo, decorrentes da manifestação do genótipo. O } \\
\text { fenótipo se modifica por alterações do meio ambiente. }\end{array}$ \\
\hline
\end{tabular}

Fonte: Dados de pesquisa. 
Como é evidenciado no quadro 3, os conceitos de genótipo e fenótipo foram modificados de forma significativa com o passar do tempo, visto que termos foram acrescentados e outros foram retirados para depois serem acrescentados novamente. Isso esclarece como os conceitos são construídos com o passar do tempo e como sofrem alterações devido às influências sociais, econômicas, históricas, desenvolvimento do conhecimento científico, entre outros.

Apesar do exposto, as modificações ocorridas não foram suficientes para que os livros contribuíssem de forma significativa para a educação científica dos sujeitos, pois continuam, em sua maioria, a expressar os conceitos em sua forma molecular clássica. Portanto, ainda há muitas alterações que precisam ser incorporadas a esses materiais com o objetivo de possibilitar aos estudantes uma maior compreensão da complexidade desses conceitos.

Entretanto, apresentar o modelo molecular clássico dos conceitos de genótipo e fenótipo dentro de uma contextualização histórica, que nos livros atuais deveriam trazer o desenvolvimento desses conceitos até a atualidade, não se configuraria como um erro na transposição didática. Porém, como destaca Martins (2006a, p. 20):

Ocorre que os autores de muitos livros didáticos utilizam uma descrição superficial e falha da História da Ciência para passar uma visão preconcebida e simplista da dinâmica científica. É preciso fazer um estudo profundo, baseado em material original, para poder compreender o que realmente se passa no processo de construção da ciência.

Para elaborar materiais de qualidade que forneçam subsídios aos docentes que são responsáveis pela transposição didática do "saber a ser ensinado", é necessária a revisão minuciosa de como se apresentam os conceitos nos livros didáticos. Desta forma, pode-se evitar que edições futuras reproduzam novamente materiais insatisfatórios no que tange a explicação de conceitos complexos, como são os de genótipo e fenótipo.

\section{A dialética antigo/novo}

Para responder a questão cinco, fez-se a exposição em um quadro que primeiramente relata se o livro apresenta ou não apresenta alguma contextualização histórica no capítulo onde se situa os conceitos de genótipo e fenótipo, sem necessariamente remeter-se aos conceitos em questão. 
Quadro 4: O livro aborda o conhecimento histórico dos conceitos de genótipo e fenótipo.

\begin{tabular}{|c|c|c|c|}
\hline $\begin{array}{l}\text { Código do } \\
\text { livro }\end{array}$ & Apresenta & $\begin{array}{c}\text { Não } \\
\text { apresenta }\end{array}$ & Como o livro apresenta \\
\hline LD1 & $\mathrm{X}$ & & Relata brevemente sobre os estudos de Mendel \\
\hline LD2 & $\mathrm{X}$ & & Destaca os estudos e contribuições de Mendel para a genética \\
\hline LD3 & $\mathrm{X}$ & & $\begin{array}{l}\text { Faz um breve relato da história do estudo da hereditariedade, } \\
\text { porém, dá maior ênfase às contribuições de Mendel. }\end{array}$ \\
\hline LD4 & & $\mathrm{X}$ & Não identificado \\
\hline LD5 & & $\mathrm{X}$ & Não identificado \\
\hline LD6 & & $\mathrm{X}$ & Não identificado \\
\hline LD7 & $\mathrm{X}$ & & Relata rapidamente sobre o desenvolvimento da genética. \\
\hline LD8 & & $\mathrm{X}$ & Não identificado \\
\hline LD9 & $X$ & & Menciona o desenvolvimento do estudo da hereditariedade \\
\hline LD10 & & $\mathrm{X}$ & Não identificado \\
\hline LD11 & & $\mathrm{X}$ & Não identificado \\
\hline LD12 & $\mathrm{X}$ & & $\begin{array}{l}\text { Faz um breve relato da história da hereditariedade, dando } \\
\text { ênfase aos estudos de Mendel. }\end{array}$ \\
\hline LD13 & $\mathrm{X}$ & & Trabalha a história dando destaque aos estudos de Mendel. \\
\hline LD14 & $\mathrm{X}$ & & $\begin{array}{l}\text { Relata sobre o desenvolvimento dos estudos } \\
\text { hereditariedade dando ênfase às contribuições de Mendel. }\end{array}$ \\
\hline LD15 & $\mathrm{X}$ & & Faz um breve comentário das contribuições de Mendel. \\
\hline LD16 & & $\mathrm{X}$ & Não identificado \\
\hline LD17 & $\mathrm{X}$ & & $\begin{array}{l}\text { Relata sobre a importância de Mendel para o desenvolvimento } \\
\text { da genética. }\end{array}$ \\
\hline LD18 & $\mathrm{X}$ & & $\begin{array}{l}\text { Faz todo um relato histórico de como se chegou aos } \\
\text { conhecimentos atuais sobre genótipo e fenótipo. }\end{array}$ \\
\hline LD19 & $\mathrm{X}$ & & Faz uma breve citação dos estudos de Mendel. \\
\hline
\end{tabular}

Fonte: Dados da Pesquisa

Como foi possível perceber, nem todos os livros introduzem contextos históricos nos capítulos onde são abordados os conceitos de genótipo e fenótipo. No entanto, omitir o processo de construção do conhecimento pode trazer prejuízos para a aprendizagem dos alunos, gerando visões aproblematicas e ahitóricas da ciência como destaca Gil Pérez et al. (2001, p. 131): “[...] transmitem-se os conhecimentos já elaborados, sem mostrar os problemas que lhe deram origem, qual foi a sua evolução, as dificuldades encontradas etc". Isso proporciona a visão da ciência como uma verdade absoluta, pronta e acabada, como evidenciam vários defensores da inserção da história da ciência em sala de aula, como Matthews (1995), El-Hani (2006), Justina (2011), entre outros.

A seguir estão dispostos alguns fragmentos para exemplificar como os livros discorrem sobre o desenvolvimento do conhecimento científico:

Gregor Mendel é originário de Heinzendorf, na Silésia (hoje Tchecoslováquia), onde nasceu a 22 de julho de 1822 . Seus pais modestos pomicultores, incutiram-lhe desde cedo o gosto pelas atividades agrícolas, em cujo exercício o futuro sábio iria encontrar mais tarde ensejo para suas notáveis descobertas [...] As experiências fundamentais de Mendel foram praticadas no jardim do convento, durante oito anos (1857-1864) tendo por objetivo os fenômenos de hereditariedade nas ervilhas. [...] Sem nos preocuparmos com as teorias sobre hereditariedade anteriores a 1900 (época em que se tornaram conhecidas as experiências e as leis de Mendel), pois aquelas teorias tem hoje unicamente um valor histórico, iniciemos nosso estudo dos fatos da genética expondo desde logo os princípios mendelianos. (LD1) 
[...]As leis básicas da hereditariedade foram descobertas pelo monge agostiniano Gregor Mendel (1822-1884), num mosteiro na cidade de Brunn na Áustria (hoje pertencente a Tchecoslovaquia). O relatório de suas pesquisas foi publicado em 1866, mas não recebeu a atenção que merecia. Somente em 1900, após a morte de Mendel, seus trabalhos foram redescobertos e compreendidos. Apartir de então tornava-se clara a importância das leis mendelianas e sua validade para todos os organismos, inclusive o próprio homem. Até hoje Mendel é conhecido como "pai da Genética”. (LD12)

Hoje sabemos que o veiculo da hereditariedade são os genes - setores da molécula de DNA presente nos cromossomos da célula. Mesmo antes dessa descoberta, as leis básicas da hereditariedade já tinha sido estabelecidas pelo monge agostiniano Gregor Mendel (1822-1884) num mosteiro da cidade de Brunn na Áustria. (LD15)

Como é possível perceber nesses fragmentos, apresentam-se breves relatos referentes a um único pesquisador, Gregor Mendel. Porém, apesar de muitos o considerarem como o precursor da genética, Mendel destinava suas pesquisas a contribuições com os conhecimentos em hibridismo e não estava consciente de suas contribuições para a hereditariedade, que ocorreram posteriormente ao seu falecimento. Quando se realizam breves relatos nos livros dando ênfase aos estudos de Mendel, isto reforça uma visão elitista e individualista da ciência, como destacam Gil Pérez et al. (2001, p. 133):

Os conhecimentos científicos aparecem como obras de gênios isolados, ignorandose o papel do trabalho coletivo e cooperativo, dos intercâmbios entre equipes [...] Em particular faz-se crer que os resultados obtidos por um só cientista ou equipe podem ser suficientes para verificar, confirmando ou refutando, uma hipótese ou toda uma teoria.

O livro LD18 é o único que traz uma história mais detalhada dos processos de construção do conhecimento até os dias atuais, sendo, também, o único que traça um retrospecto histórico sem dar ênfase a um único cientista, o que significa progressos na produção de materiais didáticos destinados ao ensino nos últimos anos da escola básica. Como pode ser observado no fragmento a seguir, presente no capítulo "Do genótipo ao fenótipo: como se expressam os genes", o livro inicia com a história de como o DNA passou a ser reconhecido como o responsável por carregar as características genéticas:

\footnotetext{
A história do DNA começa no final da Década de 1960, com a chegada o médico Friedrich Miescher $(1844$ - 1895) a universidade de Tubingen [...]. Em um de seus muitos experimentos com células do pus, Miescher obteve um precipitado que diferia quimicamente de todas as substâncias proteicas conhecidas [...]. As informações disponíveis sobre o DNA, no começo de 1950, eram como peças desencontradas de um quebra cabeça. Reunindo-as de modo coerente, o biólogo James D. Watson e o físico Francis H. C. Crick elaboraram o modelo da dupla hélice para a molécula de DNA. (LD18)
}

Desta forma, destaca-se que é de extrema relevância mostrar aos alunos como os conhecimentos são construídos, porém, para isso é necessário que os materiais sejam de 
qualidade. Trabalhar a história do processo de construção dos conhecimentos, como destacado por Matthews (1995, p. 172),

(1) motiva e atrai os alunos; (2) humaniza a matéria; (3) promove uma compreensão melhor dos conceitos científicos por traçar seu desenvolvimento e aperfeiçoamento; (4) há um valor intrínseco em se compreender certos episódios fundamentais na história da ciência -a Revolução Científica, o darwinismo, etc.; (5) demonstra que a ciência é mutável e instável e que, por isso, o pensamento científico atual está sujeito a transformações que (6) se opõem a ideologia cientificista; e, finalmente, (7) a história permite uma compreensão mais profícua do método científico e apresenta os padrões de mudança na metodologia vigente.

Entretanto, para que esses materiais não possam causar distorções na compreensão de como o conhecimento é construído, é preciso análises minuciosas tanto dos produtores quanto dos professores que realizam a escolha dos livros didáticos que serão utilizados em sala de aula.

\section{Considerações finais}

$\mathrm{Na}$ análise da transposição didática referente aos elementos de despersonalização do saber, envelhecimento moral/biológico e relação antigo/novo, percebeu-se que as despersonalizações do saber nos livros examinados não realizavam, em sua maioria, a contextualização histórica da construção dos conceitos de genótipo e fenótipo, em que apenas um livro fazia menção, em notas ao lado dos textos, à constante mudança dos conhecimentos científicos. Quanto à questão referente à citação de alguns dos envolvidos, somente dois dos livros (LD7 e LD18) analisados relatavam a introdução desses conceitos por Johannsen. Desta forma, verifica-se que muito pouco foi abordado sobre como os conceitos são construídos, o que passa a ideia de que os conhecimentos são prontos e imutáveis, quando na realidade são provisórios e se encontram em constantes transformações.

Com o envelhecimento moral/biológico, constata-se que apesar de haver mudanças na forma como o conhecimento sobre genótipo e fenótipo é apresentado nos livros didáticos, esses conceitos ainda são desenvolvidos de forma determinista, baseada principalmente no conhecimento molecular clássico. Portanto, calcada na análise da historicidade da construção desses conceitos, a forma como estes são abordados na maioria dos livros não reflete a possibilidade da história da ciência contribuir para uma educação científica quanto aos conhecimentos de genótipo e fenótipo.

Por fim, analisou-se o elemento referente à dialética antigo/novo que explicitou que, em geral, a maioria dos livros didáticos, salvo o LD18, descreviam a história de um único cientista, Gregor Mendel, pois não tem como negar as contribuições deste aos conhecimentos da genética atual. Entretanto, falar somente dele como o "pai da genética" é reforçar a ideia de 
que o conhecimento é obra de grandes gênios, porém, atualmente, sabe-se que o conhecimento é um processo de construção dinâmico com a contribuição de vários pesquisadores e não um único.

Ainda há muito que precisa ser feito para que a história e filosofia da ciência sejam consideradas um dos componentes norteadores do currículo de Biologia. É necessário, por conseguinte, produzir materiais que possibilitem aos professores trabalhar utilizando a história da ciência de forma contextualizada. Para alcançar esses objetivos é fundamental uma ação conjunta visando uma transposição didática que considere os aspectos históricos da construção do conhecimento. Além disso, precisa se pensar a formação de professores para que estes sejam capacitados a trabalhar "o saber a ser ensinado" da biologia de uma forma mais dinâmica, utilizando a história e a filosofia da ciência como uma das ferramentas norteadoras do processo de ensino e aprendizagem.

Com essas análises concluiu-se que o ensino de Biologia, calcado em uma perspectiva histórica e filosófica, pode auxiliar na compreensão de que essa ciência, assim como todas as outras, não se constitui de descobertas, mas de modelos explicativos resultantes de um processo de pesquisas realizadas por um coletivo de cientistas.

\section{Referências}

BARTH, W. L. Engenharia genética e bioética. Teocomunicação, v. 35, n. 149, p. 361-39, 2005.

BARDIN, L. Análise de conteúdo. Lisboa: Edições 70, 1977.

BATISTA, R. P.; MOHR, A.; FERRARI, N. Análise da história da ciência em livros didáticos do ensino fundamental em Santa Catarina. In: ENCONTRO NACIONAL DE PESQUISA EM ENSINO DE CIÊNCIAS, 6., 2007, Florianópolis, Anais... Florianópolis, 2008.

BECKER, F. A epistemologia do Professor: o cotidiano da escola. ed. 16, Petrópolis: Vorazes, 2013.

BIZZO, N. M. V. História da ciência e ensino: onde terminam os paralelos possíveis?. Em aberto, v. 11, n. 55, p. 29-35, 1992.

BRICCIA, V.; CARVALHO, A. M. P. Visões sobre a natureza da ciência construídas a partir do uso de um texto histórico na escola média. REEC: Revista electrónica de enseñanza de las ciencias, v. 10, n. 1, p. 1-22, 2011.

CARNEIRO, M. H. S.; GASTAL, M. L. História e filosofia das ciências no ensino de biologia. Ciência \& Educação, v. 11, n. 1, p. 33-39, 2005.

CHEVALLARD, Y. La transposición didáctica. Del saber sabio al saber enseñado. Buenos Aires: Aique, 1991. 
EL-HANI, C. N. Notas sobre o ensino de história e filosofia da ciência na educação científica de nível superior. In: SILVA, C. C. (Org.) Estudos de história e filosofia das ciências: subsídios para aplicação no ensino. São Paulo: Editora Livraria da Física, 2006, p. 3-21.

GIL-PÉREZ, D.; MONTORO, I. F.; ALÍS, J. C.; CACHAPUZ, A.; PRAIA, J. Para uma imagem não deformada do trabalho científico. Ciência \& Educação, v. 7, n. 2, p. 125-153, 2001.

JUSTINA, L. A. D. Investigação sobre um grupo de pesquisa como espaço coletivo de formação inicial de professores e pesquisadores de biologia. 2011. $238 \mathrm{f}$. Tese (Doutorado em Educação para a Ciência). Faculdade de Ciências da UNESP, Universidade Estadual Paulista, Bauru.

JOHANNSEN, W. The genotype conception of heredity. International journal of epidemiology, v. 43, n. 4, p. 989-1000, 2014.

KOLIOPOULOS, D.; DOSSIS, S.; STAMOULIS, E. The Use of History of Science Texts in Teaching Science: Two Cases of an Innovative, Constructivist Approach. Science Education Review, v. 6, n. 2, p. 44-56, 2007.

LAJOLO, M. Livro didático: um (quase) manual de usuário. Em aberto, v. 16, n. 69, p. 3-9, 1996.

MARANDINO, M. Transposição Ou Recontextualização? Sobre a Produção de Saberes Na Educação Em Museus de Ciências. Red Revista Brasileira de Educação, n. 26, p. 95-183, 2004.

MARTINS, L. A. P. A história da ciência e o ensino da biologia. Ciência \& Ensino, v. 3, n. 2, p. 18-21, 2006a.

MARTINS, L. A. P.; BRITO, A. P. O. P. Moraes. A história da ciência e o ensino da genética e evolução no nível médio: um estudo de caso. In: SILVA, C. C. (Org.) Estudos de história e filosofia das ciências: subsídios para aplicação no ensino. São Paulo: Editora Livraria da Física, 2006b. p. 245-264.

MARTINS, R. A. Introdução: A história da ciência e seus usos na educação. In: SILVA, C. C. (Org). Estudos de História e Filosofia das Ciências: subsídios para a aplicação no ensino. São Paulo: Editora Livraria da Física, 2006c. p. 17-30.

MARTINS, A. F. P. História e Filosofia da Ciência no ensino: Há muitas pedras nesse caminho. Caderno Brasileiro de Ensino de Física, v. 24, n. 1, p. 112-131, 2007.

MATTHEWS, M. S. História, filosofia e ensino de ciências: a tendência atual de reaproximação. Caderno Brasileiro de Ensino de Física, v. 12, n. 3, p. 164-214, 1995.

MEGID NETO, J.; FRACALANZA, H. O livro didático de ciências: problemas e soluções. Ciência \& Educação, v. 9, n. 2, p. 147-157, 2003. 
MELZER, E. E. M. Do saber sábio ao saber a ensinar: A transposição didática do conteúdo modelo atômico de livros de química (1931 - 2012). 2012. 555 f. Dissertação (Pós-Graduação em Educação em Ciências e em Matemática). Universidade Federal do Paraná, Curitiba.

MENEZES, A. P. A. B. Contrato didático e transposição didática: Inter-relações entre os fenômenos didáticos na iniciação à álgebra na $6^{\mathrm{a}}$ série do ensino Fundamental. 2006. $411 \mathrm{f}$. Tese (Doutorado em Educação). Centro de Educação da UFPE, Universidade Federal de Pernambuco, Pernambuco.

NEVES, K. C. R.; BARROS, R. M. O. Diferentes olhares acerca da transposição didática. Investigações em Ensino de Ciências, v. 16, n. 1, p. 103-115, 2011.

NEVES, K. C. R. Um exemplo de transposição didática: o caso das matrizes. 2009. 164 f. Dissertação (Mestrado em Educação Para a Ciência e a Matemática). Universidade Estadual de Maringá, Maringá.

NÚÑEZ, I. B.; RAMALHO, B. L.; SILVA, I. K. P.; CAMPO, A. P. N. A seleção dos livros didáticos: um saber necessário ao professor. $\mathrm{O}$ caso do ensino de Ciências. Revista Iberoamericana de Educación, v. 25, n. 4, p. 1-12 2003.

PRETTO, N. L. A ciência nos livros didáticos. Bahia: EDUFBA,1985.

ROSA, S. R. G.; SILVA, M. R. A História da Ciência nos Livros Didáticos de Biologia do Ensino Médio: uma análise do conteúdo sobre o episódio da transformação bacteriana. Alexandria: Revista de Educação em Ciência e Tecnologia, v. 3, n. 2, p. 59-78, 2010.

SILVA, C. C. Estudos de História e Filosofia das Ciências: subsídios para a aplicação no ensino. São Paulo: Editora Livraria da Física, 2006.

SILVA, M. R.; PASSOS, M. M.; BOAS, A. V. A história da dupla hélice do dna nos livros didáticos: suas potencialidades e uma proposta de diálogo. Ciência \& Educação, v. 19, n. 3, 2013.

SCHNEIDER, E. M.; JUSTINA, L. A. D.; ANDRADE, M. B. S. D.; OLIVEIRA, T. B. D.; CALDEIRA, A. M. D. A.; MEGLHIORATTI, F. A. Conceitos de gene: construção históricoepistemológica e percepções de professores do ensino superior. Investigações em Ensino de Ciências, v. 16, n.2, 201-222, 2011.

SCHNEIDER, E. M.; JUSTINA, L. A. D.; MEGLHIORATTI, F. A. Investigação do desenvolvimento de um módulo didático sobre o conceito de gene na licenciatura em ciências biológicas. Experiências em Ensino de Ciências, v. 8, n. 3, p. 1-21, 2013.

WATSON, J.; CRICK, F. A structure for desoxyribose nucleic acid. Nature, v. 171, n. 4356, p. 737- 738, 1953.

\section{SOBRE AS AUTORAS}

ALINE ALVES DA SILVA. Graduada em Ciências Biológicas pela Universidade Estadual do Oeste do Paraná - UNIOESTE (2014). Pós-graduada em Ensino de Ciências e Matemática Pela Universidade Estadual do Oeste do Paraná - UNIOESTE (2016), Mestra em Educação pela Universidade Estadual do Oeste do Paraná - UNIOESTE (2017) e Doutoranda do curso 
de Pós-Graduação em Educação para a Ciência e a Matemática pela Universidade Estadual de Maringá - UEM (2017). Participou do Programa Institucional de Bolsas de Iniciação à Docência (PIBID) pelo período de três anos. Integrante do Grupo de Pesquisa em Educação em Ciências e Biologia - GECIBIO da Universidade Estadual do Oeste do Paraná, UNIOESTE. Participante do Projeto de Pesquisa Comunidade de Prática (CoP) de Biologia: pesquisa e ensino - Unioeste/UEM. Atuando principalmente nos seguintes temas: Ensino de Biologia, Ensino de Genética, História e Filosofia da ciência e Ciência, Epistemologia da Ciência e Tecnologia e Sociedade (CTS).

LOURDES APARECIDA DELLA JUSTINA. Licenciada em Ciências Biológicas pela Universidade Federal de Santa Maria (1998). Mestre em Educação pela Universidade Federal de Santa Catarina (2001). Doutora em Educação para a Ciência pela Universidade Estadual Paulista Júlio de Mesquita Filho (2011). É uma das líderes do Grupo de Pesquisa em Educação em Ciências e Biologia. Professora da Universidade Estadual do Oeste do Paraná, atuando na área de Educação em Ciências, principalmente nos seguintes temas: avaliação nos processos de ensino e aprendizagem; formação de professores e história e epistemologia do conhecimento científico.

Recebido: 02 de junho de 2017.

Revisado: 15 de agosto de 2017.

Aceito: 17 de agosto de 2017. 